\title{
Phosphirenium lons as Masked Phosphenium Catalysts: Mechanistic Evaluation and Application in Synthesis
}

\author{
Danila Gasperini, Samuel E. Neale, Mary F. Mahon, Stuart A. Macgregor,* and Ruth L. Webster* \\ Cite This: ACS Catal. 2021, 11, 5452-5462 \\ Read Online
}

ABSTRACT: The utilization of phosphirenium ions is presented; optimized and broadened three-membered ring construction is described together with the use of these ions as efficient pre-catalysts for metal-free carbonyl reduction with silanes. Full characterization of the phosphirenium ions is presented, and initial experimental and computational mechanistic studies indicate that these act as a "masked phosphenium" source that is accessed via ring opening. Catalysis proceeds via associative transfer of $\left\{\mathrm{Ph}_{2} \mathrm{P}^{+}\right\}$to a carbonyl nucleophile, $\mathrm{H}-\mathrm{SiR}_{3}$ bond addition over the $\mathrm{C}=\mathrm{O}$ group, and associative displacement of the product by a further equivalent of the carbonyl substrate, which completes the catalytic cycle. A competing off-cycle

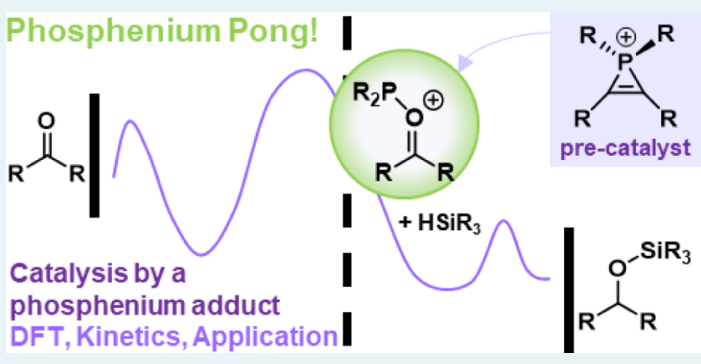
process leading to vinyl phosphine formation is detailed for the hydrosilylation of benzophenone for which an inverse order in [silane] is observed. Experimentally, the formation of side products, including off-cycle vinyl phosphine, is favored by electrondonating substituents on the phosphirenium cation, while catalytic hydrosilylation is promoted by electron-withdrawing substituents. These observations are rationalized in parallel computational studies.

KEYWORDS: phosphenium ions, phosphirenium ions, organocatalysis, reaction mechanism studies, density functional theory, hydrosilylation

\section{INTRODUCTION}

The chemistry of the three-membered phosphacycle, the phosphirenium ion, first appeared in the literature at the beginning of the $1980 \mathrm{~s},{ }^{1}$ along with a number of theoretical studies that considered their stabilization by $\sigma^{*}$-aromaticity. ${ }^{2}$ The chemistry to date is dominated by the use of these species as reagents in synthesis; exploitation of their catalytic Lewis acidic properties has yet to be reported. The first example of a stabilized three-membered phosphirene-tungsten ring was reported by Marinetti and Mathey in $1982^{3}$ (Scheme 1a). A year later, Hogeveen and Breslow reported and characterized phosphirenium salts by formal addition of halophosphines to alkynes, ${ }^{4}$ a method that was further improved using aminephosphenium ions $\left[i \mathrm{Pr}_{2} \mathrm{NPCl}\right]^{+}\left[\mathrm{AlCl}_{4}\right]^{-}($Scheme $1 \mathrm{~b}){ }^{5}$ Other routes for their synthesis or methods for structural elaboration have been developed, ${ }^{6-8}$ but it was only in 2017 , when Hirano and Miura reported the synthesis of highly functionalized organophosphines postulated to proceed via a phosphirenium intermediate, that the application in practical organic synthesis was reported (Scheme 1c). ${ }^{9}$ They have since expanded their methodology to the synthesis of dibenzophospholes, ${ }^{10,11}$ while other groups have reported functionalization of phosphine oxides in the presence of $\mathrm{Tf}_{2} \mathrm{O} .{ }^{12}$

Phosphirenium ions pose an interesting mechanistic challenge: they possess both electrophilic phosphorus and a low-lying $\pi^{*}$-acceptor centered on the highly activated carbon-carbon double bond in the ring. Both could behave as Lewis acidic sites for the activation of organic substrates and so possess exciting opportunities for selective or divergent reactivity. However, we herein report on the unexpected ability of phosphirenium ions to undergo ring opening and subsequent alkyne displacement via nucleophilic trapping of a phosphenium ion $\left\{\mathrm{Ph}_{2} \mathrm{P}^{+}\right\}$by carbonyl reagents (Scheme 1d). Onward reaction with a silane and a further equivalent of carbonyl releases the reduced carbonyl product and regenerates the highly active phosphenium adduct, which is the active catalyst. Divalent phosphenium ions are highly elusive species, relying on lone pair stabilization of the empty phosphorus porbital by adjacent heteroatoms (e.g., $\mathrm{N}$ - or P-donors) without which they are challenging to detect and characterize. ${ }^{13}$ It is worth noting that divalent phosphenium species, in the form of $\mathrm{N}$-heterocyclic phosphenium ions, have recently started to gather interest, ${ }^{14}$ not least due to their catalytic capabilities, which are as yet unproven with a simple $\left\{\mathrm{Ar}_{2} \mathrm{P}^{+}\right\}$catalyst. Here, our synergistic experimental and computational approach strongly supports our assertion of easy-to-prepare and -handle phosphirenium ions acting as a masked phosphenium catalyst

Received: March 11, 2021

Revised: April 2, 2021

Published: April 20, 2021 
Scheme 1. (a,b) Different Approaches to the Synthesis of Phosphirenium Ions; (c) Functionalization via a Phosphirenium Ion; (d) This Work, where Mechanistic Investigations Indicate that a Phosphirenium Pre-catalyst Acts as a Masked Phosphenium Ion, Which is Itself the Active Catalyst

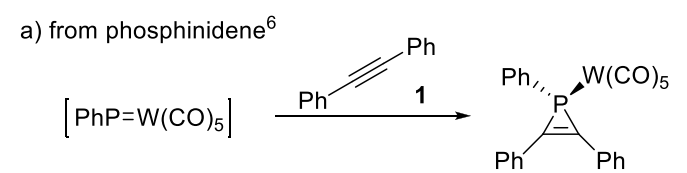

b) from halophosphane or protected phosphenium salts

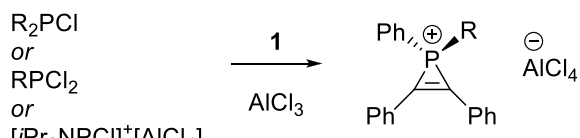

$\left[\mathrm{Pr}_{2} \mathrm{NPCl}\right]^{+}\left[\mathrm{AlCl}_{4}\right]$
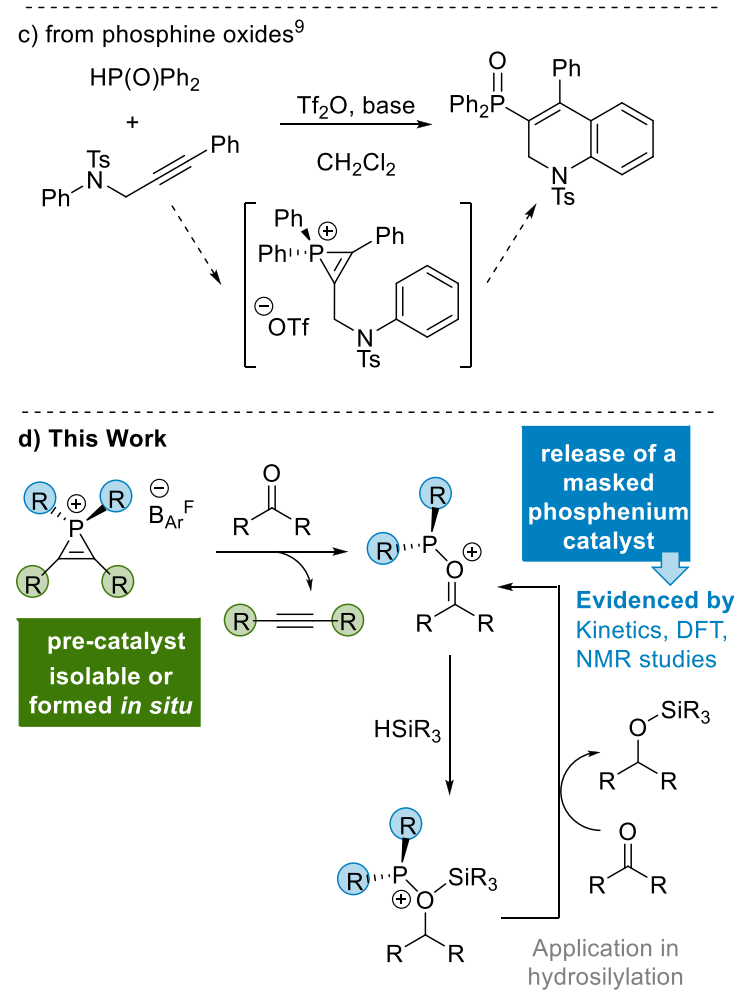

of the form $\left\{\mathrm{Ph}_{2} \mathrm{P}^{+}\right\}$, stabilized by a Lewis basic carbonyl oxygen atom. An advantage of the work reported here is the ease of synthesis, with a range of phosphirenium pre-catalysts being readily prepared or formed in situ for use in catalysis.

\section{RESULTS AND DISCUSSION}

2.1. Synthesis and Characterization of Phosphirenium lons. Due to the practicality of the reaction, Hirano and Miura's procedure (where the phosphirenium ion was detected but not isolated $)^{9,11,15}$ was employed for the synthesis of phosphirenium ion 3.OTf (Table 1, entry 1 ). Formation of 3 . OTf is observed by following the reaction via ${ }^{31} \mathrm{P}\left\{{ }^{1} \mathrm{H}\right\} \mathrm{NMR}$ spectroscopy, where a characteristic peak at $-108.3 \mathrm{ppm}$ is obtained. ${ }^{9}$ To optimize the protocol, different activating agents were reacted with diphenyl acetylene 1 and secondary phosphine oxide (SPO) 2 in $\mathrm{CDCl}_{3}$. 3.OTf does not form when using triflate salts, such as silver or iron triflates (entries 2
Table 1. Optimization of the Synthesis of Phosphirenium Ions $^{a}$

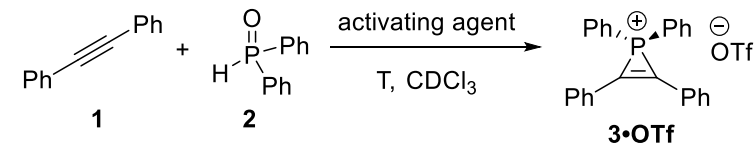

\begin{tabular}{clcl}
\hline entry & activating agent & $\mathrm{T}\left({ }^{\circ} \mathrm{C}\right)$ & conversion to 3·OTf \\
\hline 1 & $\mathrm{Tf}_{2} \mathrm{O}$ & 80 & $60 \%$ \\
2 & $\mathrm{Fe}(\mathrm{OTf})_{2}$ & 80 & 0 \\
3 & $\mathrm{AgOTf}$ & 80 & 0 \\
4 & $\mathrm{HOTf}$ & 80 & 0 \\
5 & $\mathrm{HOTf} / \mathrm{PhSiH}_{3}$ & 80 & $\mathrm{Ph}_{2} \mathrm{PH}$ (major) \\
6 & $\mathrm{Ac}_{2} \mathrm{O}$ & 80 & several products \\
7 & $\left.\mathrm{O}^{b} \mathrm{CO}_{2} t \mathrm{Bu}\right)_{2}$ & 80 & 0 \\
8 & $\mathrm{Tf}_{2} \mathrm{O}$ & $\mathbf{6 0}$ & $>99 \%{ }^{c}\left(98 \%{ }^{d}\right)$
\end{tabular}

${ }^{a}$ Reaction conditions $1(0.2 \mathrm{mmol}), 2(0.2 \mathrm{mmol})$, activating agent $(0.2 \mathrm{mmol})$, and $\mathrm{CDCl}_{3}(0.4 \mathrm{mM}) .{ }^{b}$ See the Supporting Information. ${ }^{c} \mathrm{CD}_{3} \mathrm{CN}$. ${ }^{d}$ Spectroscopic yield analyzed by inverse-gated ${ }^{31} \mathrm{P}\left\{{ }^{1} \mathrm{H}\right\}$ NMR spectroscopy with $\mathrm{PPh}_{3}$ as an internal standard.

and 3 ), or by Brønsted acid activation with triflic acid ${ }^{16}$ (entry 4) or activated triflic acid (entry 5). Acetic anhydride does activate 2 , with the formation of $\mathrm{Ph}_{2} \mathrm{P}(\mathrm{OAc})^{17}$ and $\mathrm{Ph}_{2} \mathrm{P}(\mathrm{O})$ $\mathrm{PPh}_{2} \cdot{ }^{18}$ However, these species do not react further with $\mathbf{1}$ (entry 6). Di-tert-butyl dicarbonate $\left(\mathrm{Boc}_{2} \mathrm{O}\right)$ is not effective for this transformation, and even at higher temperatures, $\mathbf{1}$ and $\mathbf{2}$ are recovered (entry 7). Following a brief solvent and temperature screening, ${ }^{19}$ the optimal conditions were determined to be $\mathrm{CH}_{3} \mathrm{CN}$ at $60{ }^{\circ} \mathrm{C}$ for $30 \mathrm{~min}$, which give full conversion to $3 \cdot 0$ Tf (entry 8 ).

Adding 1 equiv of $\mathrm{NaB}_{\mathrm{Ar}}^{\mathrm{F}}$ to the optimized reaction mixture of $\mathbf{1}, 2$, and $\mathrm{Tf}_{2} \mathrm{O}$ in $\mathrm{CD}_{3} \mathrm{CN}$ forms $3 \cdot \mathbf{B}_{\mathrm{Ar}}^{\mathrm{F}}$, which is isolated in $66 \%$ yield (Figure 1). A small downfield shift is observed in the ${ }^{31} \mathrm{P}\left\{{ }^{1} \mathrm{H}\right\}$ NMR spectrum from $-108.3 \mathrm{ppm}$ for $3 \cdot \mathrm{OTf}$ to $-109.1 \mathrm{ppm}$ for $3 \cdot \mathbf{B}_{\mathrm{Ar}}^{\mathrm{F}}$; the disappearance of the triflate peak at $-79.3 \mathrm{ppm}$ is observed by ${ }^{19} \mathrm{~F}$ NMR spectroscopy and substituted by a ${ }^{-} \mathrm{B}_{\mathrm{Ar}}{ }^{\mathrm{F}}$ counterion at $-62.5 \mathrm{ppm}$. Counterion exchange is not observed when using sodium or silver salts,
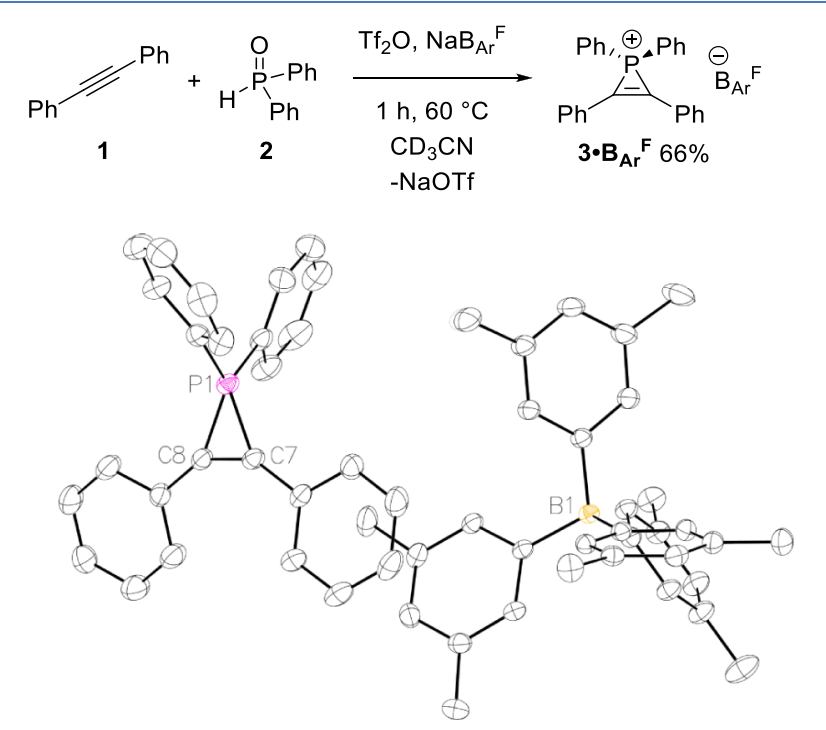

Figure 1. Counterion exchange at the phosphirenium ion. Isolated yield presented. ORTEP view of $3 \cdot \mathbf{B}_{\mathrm{Ar}}^{\mathrm{F}}$ showing a thermal ellipsoid at $30 \%$ probability levels. $\mathrm{H}, \mathrm{F}$, and minor components of disordered anion $\mathrm{C}$ atoms were omitted for clarity. ${ }^{23}$ 
such as $\mathrm{NaBF}_{4}$ or $\mathrm{AgNTf}_{2}$, and 3.OTf is recovered; with $\mathrm{AgSbF}_{6}$ and $\mathrm{AgBF}_{4}$, decomposition of the starting material is observed via ${ }^{31} \mathrm{P}\left\{{ }^{1} \mathrm{H}\right\},{ }^{19} \mathrm{~F}$, and ${ }^{1} \mathrm{H}$ NMR spectroscopy. ${ }^{20}$ The structure of $3 \cdot \mathrm{B}_{\mathrm{Ar}} \mathrm{F}$ was confirmed by single-crystal X-ray diffraction analysis. The bond metrics associated with this structure are in line with other examples of phosphirenium cations, for example, the ring $\mathrm{P}-\mathrm{C}$ distances are 1.748(2) and 1.746(3) $\AA$, and the $\mathrm{C}=\mathrm{C}$ bond distance is 1.340 (4) $\AA$; both are similar to reports from Mathey, Wild, and Cowley. ${ }^{3,6,7,21}$ The alternating single and double bonds show that the structure depicted is the dominant resonance form of the phosphirenium ion in the solid state. This species represents the first isolated phosphirenium ion with a borate counterion. ${ }^{22}$

With the optimized conditions in hand, the generality of the methodology was explored (Figure 2). Some of the phosphirenium ions were very sensitive and could only be characterized in situ $(5 \cdot 0 \mathrm{OTf}, 6 \cdot \mathrm{OTf}, 7 \cdot \mathrm{OTf}, 8 \cdot \mathrm{OTf}$, and $\mathbf{1 0}$ OTf proved particularly challenging; see the Supporting Information for spectral data). The use of different substituted SPOs, bearing bearing aryl or alkyl groups, is well tolerated. For example, using $\mathrm{Cy}_{2} \mathrm{P}(\mathrm{O}) \mathrm{H}, \mathbf{4} \cdot \mathrm{OTf}$ and $\mathbf{4} \cdot \mathbf{B}_{\mathrm{Ar}}{ }^{\mathrm{F}}$ are isolated in high yields ( 97 and $98 \%$, respectively). These species display downfield ${ }^{31} \mathrm{P}\left\{{ }^{1} \mathrm{H}\right\}$ NMR signals compared to 3 , with a singlet at -85.4 and $-86.5 \mathrm{ppm}$, respectively, due to the increased electron donation of the alkyl substituents. There is only a very modest difference in the ${ }^{31} \mathrm{P}$ chemical shift observed between the ions bearing different anions, $3 \cdot \mathbf{O T f}$ versus $3 \cdot \mathrm{B}_{\mathrm{Ar}}{ }^{\mathrm{F}} \Delta \delta=0.8$ and $4 \cdot \mathrm{OTf}$ versus $4 \cdot \mathrm{B}_{\mathrm{Ar}}^{\mathrm{F}} \Delta \delta=1.1 \mathrm{ppm}$, which is as expected given the non-coordinating nature of the counterions.

Mixed SPOs bearing alkyl and phenyl groups, such as $t \mathrm{BuPhP}(\mathrm{O}) \mathrm{H}$ and $\mathrm{CyPhP}(\mathrm{O}) \mathrm{H}$, are also well tolerated with full conversion after $1 \mathrm{~h}$ to form $5 \cdot \mathbf{O T f}^{24}$ and $6 \cdot 0 \mathrm{Tf}$, with ${ }^{31} \mathrm{P}\left\{{ }^{1} \mathrm{H}\right\}$ NMR signals at -97.1 and $-93.3 \mathrm{ppm}$, respectively. Varying the alkyne was also explored; phenyl acetylene and $\mathrm{Cy}_{2} \mathrm{P}(\mathrm{O}) \mathrm{H}$ lead to full conversion to $7 \cdot \mathbf{O T f}$ with a phosphorus signal at $-80.2 \mathrm{ppm}$ and a downfield signal for the terminal $\mathrm{C}-\mathrm{H}$ at $8.4 \mathrm{ppm}$. For all phosphirenium species presented, there are deshielded signals in the proton and carbon NMR spectra, which can be explained by the resonance structure of the phosphirenium ion. ${ }^{25,26}$ 1-Phenyl-1-propyne reacts well with 2 to form $8 \cdot 0$ Tf with a ${ }^{31} \mathrm{P}$ signal at $-103.6 \mathrm{ppm}$. Further functionalization of the alkyne is tolerated with 9.OTf $(38 \%)$ and $\mathbf{1 0} \cdot$ OTf $(64 \%)$ isolated using the optimized conditions. The phosphorus signals for 9.OTf and 10.0Tf appear at $\delta$ -104.3 and $-110.9 \mathrm{ppm}$, respectively, versus $-108.3 \mathrm{ppm}$ for 3.OTf; thus, by this measure, the alkyne substituents only have a minor impact on $\mathrm{P}^{+}$electronics, but as we show below, the same substituents have a dramatic effect on catalytic reactivity. Crystallization is not limited to $\mathrm{B}_{\mathrm{Ar}}^{\mathrm{F}}$ counterions, and $\mathrm{X}$-ray single-crystal analysis of $\mathbf{1 0} \cdot$ OTf confirms the three-membered structure of this phosphirenium species (Figure 2, bottom), with similar metrics as observed for 3 . Short contacts between the counterion and the phosphirenium substituents are observed, although no direct P $\cdots \mathrm{O}$ interaction was found, probably due to the steric effect of the two phenyl rings compared to, for example, the mixed $\mathrm{Ph}$ and $\mathrm{Me}$ system reported by Wild.?

2.2. Hydrosilylation Optimization. With these phosphirenium species in hand, we explored the use of phosphirenium ions as pre-catalysts for the hydrosilylation of aldehydes and ketones. We opted for this transformation

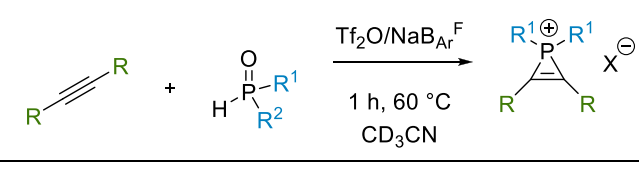

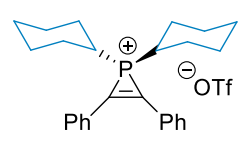

4.OTf $97 \%$

$\delta-85.4 \mathrm{ppm}$

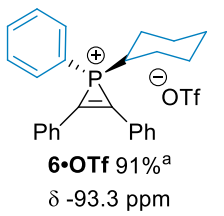

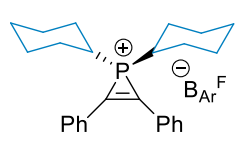

$\mathbf{4} \cdot \mathbf{B}_{\text {Ar }}{ }^{\mathbf{F}} 98 \%$

$\delta-86.5 \mathrm{ppm}$

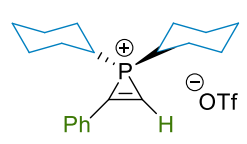

$\mathbf{7 \cdot O T f ^ { b }} 91 \%^{a}$ $\delta-80.2$ ppm

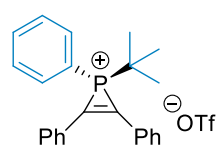

5.0Tf $66 \%{ }^{a}$

$\delta-97.1 \mathrm{ppm}$

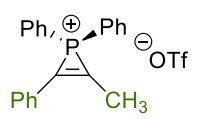

8.0Tf $95 \%{ }^{a}$ $\delta-103.6 \mathrm{ppm}$
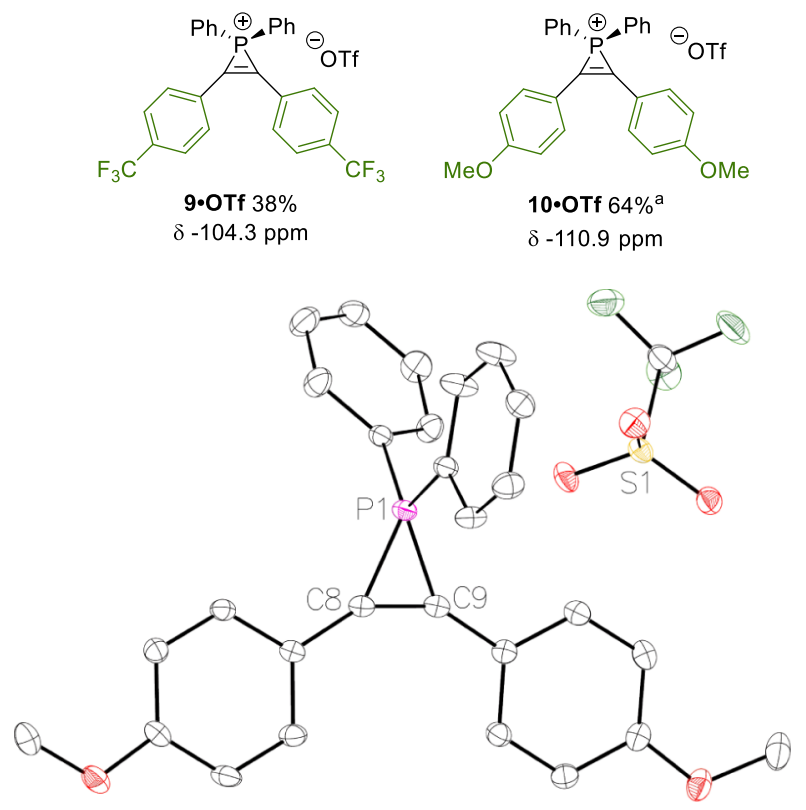

Figure 2. Synthesis of phosphirenium ions; alkyne $(0.2-0.5 \mathrm{mmol})$, phosphine oxide $(0.2-0.5 \mathrm{mmol}), \mathrm{Tf}_{2} \mathrm{O}(0.2-0.5 \mathrm{mmol}), \mathrm{NaB}_{\mathrm{Ar}}{ }_{\mathrm{F}}$ $(0.2-0.5 \mathrm{mmol}), \mathrm{CD}_{3} \mathrm{CN}, 60{ }^{\circ} \mathrm{C}$. Isolated yield presented; ${ }^{a}$ spectroscopic yield analyzed by inverse-gated ${ }^{31} \mathrm{P}\left\{{ }^{1} \mathrm{H}\right\}$ NMR spectroscopy with $\mathrm{PPh}_{3}$ as an internal standard; ${ }^{\mathrm{b}} \mathrm{CD}_{3} \mathrm{Cl}$. ORTEP view of $10.0 \mathrm{OTf}$ showing a thermal ellipsoid at $30 \%$ probability levels. $\mathrm{H}$ atoms were omitted for clarity. ${ }^{27}$

because it would allow comprehensive mechanistic investigations using a range of experimental techniques.

Initial studies were conducted with $10 \mathrm{~mol} \%$ phosphirenium species $4 \cdot B_{A r}{ }^{\mathrm{F}}$, prepared and activated in situ prior to the addition of the substrates, benzophenone $\mathbf{1 1}$ and dimethylphenyl silane 12, in an equimolar ratio. The reaction was monitored by ${ }^{1} \mathrm{H}$ NMR spectroscopy and examined after $18 \mathrm{~h}$ of reaction at r.t. (Table 2). Initial results were promising with $44 \%$ total conversion of 11 (entry 1 ) as $28 \% 13 a$ and $16 \% 14 a$. By increasing the temperature to $80{ }^{\circ} \mathrm{C}$ (entry 2), full conversion of the starting material is observed with $84 \%$ formation of 13a, while $16 \%$ 14a persists. Using $10 \mathrm{~mol} \%$ isolated $\mathbf{4} \cdot \mathrm{B}_{\mathrm{Ar}}{ }^{\mathrm{F}}$, lower conversions (73\%) are observed after 18 $\mathrm{h}$ (entry 3), with $58 \%$ 13a. Isolated pre-catalyst $3 \cdot \mathbf{B}_{\mathrm{Ar}}{ }^{\mathrm{F}}$ shows higher reactivity, with increased conversion to 14 a versus 13a at $10 \mathrm{~mol} \%$ loading (entry 5). When phosphirenium triflate 
Table 2. Optimization Reduction of Carbonyls with Silanes ${ }^{a}$

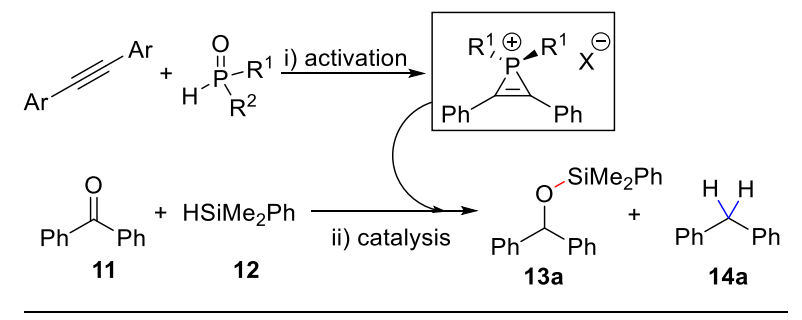

$$
{ }_{\mathbf{4} \cdot \mathrm{B}_{\mathbf{A r}}{ }^{\mathrm{F}}}^{\mathrm{C} \cdot \mathrm{B}_{\mathbf{A r}}^{\mathrm{F}}}
$$

\begin{tabular}{|c|c|c|c|c|}
\hline entry & catalyst ( $\mathrm{mol} \%)$ & temp. & $13 a^{b}$ & $14 a^{b}$ \\
\hline 1 & $\mathbf{4} \cdot \mathbf{B}_{\mathrm{Ar}}^{\mathrm{F}}(10)$ & r.t. & 28 & 16 \\
\hline 2 & $4 \cdot \mathbf{B}_{\mathrm{Ar}}^{\mathrm{F}}(10)$ & $80{ }^{\circ} \mathrm{C}$ & 84 & 16 \\
\hline $3^{b}$ & $\mathbf{4} \cdot \mathbf{B}_{\mathrm{Ar}}^{\mathrm{F}}(10)$ & $80^{\circ} \mathrm{C}$ & 58 & 15 \\
\hline 4 & $3 \cdot \mathbf{B}_{\mathrm{Ar}}^{\mathrm{F}}(10)$ & $80{ }^{\circ} \mathrm{C}$ & 21 & 75 \\
\hline $5^{b, c}$ & $3 \cdot \mathbf{B}_{\mathrm{Ar}}^{\mathrm{F}}(10)$ & $80{ }^{\circ} \mathrm{C}$ & $>99$ & \\
\hline $5^{c}$ & $4 \cdot \mathbf{B}_{\mathrm{Ar}}^{\mathrm{F}}(5)+2,6$-lutidine $(5)$ & $80{ }^{\circ} \mathrm{C}$ & $>99$ & \\
\hline $6^{c}$ & $3 \cdot \mathbf{B}_{\mathrm{Ar}}^{\mathrm{F}}(5)+2,6$-lutidine $(5)$ & $60{ }^{\circ} \mathrm{C}$ & $>99$ & \\
\hline $7^{d}$ & $9 \cdot \mathbf{B}_{\mathrm{Ar}}{ }^{\mathbf{F}}(5)+2,6$-lutidine $(5)$ & $60{ }^{\circ} \mathrm{C}$ & $>99$ & \\
\hline $8^{e}$ & $\mathbf{1 0} \cdot \mathbf{B}_{\mathrm{Ar}}^{\mathrm{F}}(5)+2,6$-lutidine $(5)$ & $80{ }^{\circ} \mathrm{C}$ & & \\
\hline 9 & $3 \cdot \mathbf{B}_{\mathrm{Ar}}^{\mathrm{F}}(10)+\mathrm{NEt}_{3}(10)$ & $80{ }^{\circ} \mathrm{C}$ & 59 & \\
\hline 10 & $3 \cdot \mathbf{B}_{\mathrm{Ar}}^{\mathrm{F}}(10)+$ pyridine $(10)$ & $80^{\circ} \mathrm{C}$ & 52 & \\
\hline 11 & $3 \cdot \mathbf{B}_{\mathrm{Ar}}^{\mathrm{F}}(10)+\mathrm{K}_{2} \mathrm{CO}_{3}(10)$ & $80{ }^{\circ} \mathrm{C}$ & & \\
\hline
\end{tabular}

$$
\begin{aligned}
& 10 \cdot \mathrm{B}_{\mathrm{Ar}}{ }^{\mathrm{F}} \text { or } 9 \cdot \mathrm{B}_{\mathrm{Ar}}{ }^{\mathrm{F}} \\
& \mathrm{Ar}=4-\mathrm{OMeC}_{6} \mathrm{H}_{4} \\
& \text { or } 4-\mathrm{CF}_{3} \mathrm{C}_{6} \mathrm{H}_{4}
\end{aligned}
$$

${ }^{a}$ Reaction condition: (i) activation step $\mathrm{R}_{2} \mathrm{P}(\mathrm{O}) \mathrm{H}(5-10 \mathrm{~mol} \%)$, $\mathrm{Tf}_{2} \mathrm{O}$ (5-10 mol \%), $\mathrm{NaB}_{\mathrm{Ar}}{ }^{\mathrm{F}}$ (5-10 mol \%), 1 (5-10 mol \%), $\mathrm{CD}_{3} \mathrm{CN}(0.41 \mathrm{M}), 60{ }^{\circ} \mathrm{C}$, and $30 \mathrm{~min}$; (ii) benzophenone $11(0.25$ mmol), dimethylphenyl silane $12(0.25 \mathrm{mmol}), 18 \mathrm{~h}$, and conversion. ${ }^{b}$ Isolated pre-catalyst. ${ }^{c} 5 \mathrm{~h} .{ }^{d} 1 \mathrm{~h} .{ }^{e}>99 \%$ after $58 \mathrm{~h}$.

species are used, such as $3 \cdot \mathrm{OTf}$ or $4 \cdot \mathrm{OTf}$, only deoxygenation occurs with full conversion into 14a; this is due to hydrogen release from silane reacting with co-catalytic $\mathrm{TfOH}$ (formed from $\left.\mathrm{Tf}_{2} \mathrm{O}\right){ }^{28}$ Thus, in line with Miura's recent studies on phosphirenium-derived heterocycles, ${ }^{9,11}$ we also note that the use of a base is crucial to quench $\mathrm{TfOH}$ released during precatalyst formation and therefore increase the selectivity toward 13a. See Table S2 in the Supporting Information where comprehensive benchmarking and optimization were undertaken demonstrating that not only does $\mathrm{TfOH}$ lead exclusively to the deoxygenation product 14a but also that superior hydrosilylation catalysis takes place using a phosphirenium precatalyst compared to the equivalent reaction using $\mathrm{TfOPPh}_{2}$. A total of $5 \mathrm{~mol} \% 2$,6-lutidine was added to $5 \mathrm{~mol} \%$ in situprepared pre-catalyst $4 \cdot B_{\mathrm{Ar}}^{\mathrm{F}}$ prior to addition of substrates $\mathbf{1 1}$ and 12, and the selective formation of 13a is observed ( $5 \mathrm{~h}, 80$ ${ }^{\circ} \mathrm{C}, \mathrm{CD}_{3} \mathrm{CN}$, entry 5 ). Changing to $3 \cdot \mathrm{B}_{\mathrm{Ar}}{ }^{\mathrm{F}}$, with $5 \mathrm{~mol} \% 2,6-$ lutidine, gives good reactivity at lower temperature (entry 6), and further improvement is seen with the electron-poor phosphirenium species $9 \cdot \mathbf{B}_{\mathrm{Ar}}^{\mathrm{F}}$, for which reaction with $5 \mathrm{~mol} \%$ 2,6-lutidine leads to full conversion into $13 \mathrm{a}$ at $60^{\circ} \mathrm{C}$ after only $1 \mathrm{~h}$ (entry 7 ). In contrast, electron-rich $\mathbf{1 0} \cdot \mathbf{B}_{\mathrm{Ar}}^{\mathrm{F}}$ reacted at a slower rate with full conversion to the hydrosilylation product requiring $58 \mathrm{~h}$ at $80^{\circ} \mathrm{C}$ (entry 8 ). Clearly the electronics of the alkyne used to prepare the phosphirenium pre-catalyst play a substantial role in catalytic competency. Screening of the base with $10 \mathrm{~mol} \% 3 \cdot \mathbf{B}_{\mathrm{Ar}}^{\mathrm{F}}$ as the catalyst of choice shows lower conversion to $13 \mathrm{a}$ when using $\mathrm{NEt}_{3}$ and pyridine (entry 9 and 10) with 59 and $52 \%$, respectively, and recovery of the starting materials with $\mathrm{K}_{2} \mathrm{CO}_{3}$ (entry 11 ) after $18 \mathrm{~h}$ at $80{ }^{\circ} \mathrm{C}$. These results show that a slightly bulkier, aromatic organic base like 2,6-lutidine is most effective. ${ }^{29}$

2.3. Mechanistic Studies. We initiated our mechanistic investigations by analyzing the catalytic reaction mixture, using in situ-prepared $\mathbf{3} \cdot \mathbf{B}_{\mathrm{Ar}} \mathbf{F}$, by NMR spectroscopy (Scheme 2a). After $30 \mathrm{~min}$, our standard reaction in $\mathrm{CD}_{3} \mathrm{CN}$ only shows the starting material $\left(\mathrm{H}_{2} \mathrm{SiMePh} \mathrm{12,-16.9} \mathrm{ppm)} \mathrm{and} \mathrm{product}\right.$ (13a, $8.3 \mathrm{ppm}$ ) in the ${ }^{29} \mathrm{Si}\left\{{ }^{1} \mathrm{H}\right\}$ NMR spectrum. However, a plethora of species are observed in the ${ }^{31} \mathrm{P}\left\{{ }^{1} \mathrm{H}\right\}$ NMR spectrum, with the major species being $3 \cdot \mathrm{B}_{\mathrm{Ar}}{ }^{\mathrm{F}}$ at -108.5 ppm, along with $\mathrm{P}_{2} \mathrm{Ph}_{4}$ at $-17.8 \mathrm{ppm},(E)$-(1,2-diphenylvinyl)diphenylphosphine at $7.1 \mathrm{ppm},{ }^{9}$ smaller amounts of $(Z)-(1,2-$ diphenylvinyl)diphenylphosphine at $-7.4 \mathrm{ppm}^{30}$ and benzhydryl diphenylphosphinate at $36.5 \mathrm{ppm} .{ }^{31}$ While phosphines are known to facilitate hydrofunctionalization of carbonyls, ${ }^{32}$ noteworthy is the lack of catalytic activity observed using 10 mol \% $\mathrm{HPPh}_{2}$ or $\mathrm{P}_{2} \mathrm{Ph}_{4}$.

A stoichiometric reaction to form $3 \cdot \mathbf{B}_{\mathrm{Ar}}{ }^{\mathrm{F}}$ with subsequent addition of 2,6-lutidine and $\mathbf{1 2}$ results in two new species by ${ }^{29} \mathrm{Si}\left\{{ }^{1} \mathrm{H}\right\}$ NMR spectroscopy. The major species is identified as $\mathrm{Me}_{2} \mathrm{SiHOTf}$ at $23 \mathrm{ppm}$, formed by the facile cleavage of the silane phenyl group. ${ }^{33}$ Analysis of the mixture by ${ }^{31} \mathrm{P}\left\{{ }^{1} \mathrm{H}\right\}$ NMR spectroscopy shows $3 \cdot \mathrm{B}_{\mathrm{Ar}}^{\mathrm{F}}, \mathrm{P}_{2} \mathrm{Ph}_{4}$, and vinyl phosphine as per the catalytic reaction, along with $\mathrm{HPPh}_{2}$ with its characteristic peak at $-40 \mathrm{ppm}$ (Scheme $2 \mathrm{~b}$ ). Finally, when performing the same stoichiometric study in the presence of benzophenone 11 and analyzing the mixture after $10 \mathrm{~min}$ by ${ }^{29} \mathrm{Si}\left\{{ }^{1} \mathrm{H}\right\}$ NMR spectroscopy, we observe 13a at $8.3 \mathrm{ppm}$ but no traces of silyl triflate ( $\mathrm{Me}_{2} \mathrm{SiHOTf}$ or $\left.\mathrm{Me}_{2} \mathrm{PhSiOTf}\right) .{ }^{33}$ The latter mixture was also analyzed by ${ }^{31} \mathrm{P}\left\{{ }^{1} \mathrm{H}\right\}$ NMR spectroscopy, which shows the presence of $3 \cdot \mathbf{B}_{\mathrm{Ar}}^{\mathrm{F}}$, vinyl phosphine, and $\mathrm{P}_{2} \mathrm{Ph}_{4}$, but no traces of $\mathrm{HPPh}_{2}$ are visible at any point of the analysis (Scheme 2c).

When performing hydrosilylation to form 13a using $10 \mathrm{~mol}$ $\% \mathbf{9} \cdot \mathbf{B}_{\mathrm{Ar}}^{\mathrm{F}}$ pre-catalyst and 2,6-lutidine, we also observe the formation of substituted vinyl phosphine [i.e., (E)-(1,2-bis(4(trifluoromethyl)phenyl)vinyl)diphenylphosphine] in situ. Hydrosilylation to form 13a using $10 \mathrm{~mol} \% \mathbf{1 0} \cdot \mathbf{B}_{\mathrm{Ar}}^{\mathrm{F}}$ pre-catalyst and 2,6-lutidine gives a complex array of peaks in the ${ }^{31} \mathrm{P}$ NMR spectrum, making identification difficult although likely including vinyl phosphines.

The use of $20 \mathrm{~mol} \%(E)$-(1,2-diphenylvinyl)diphenylphosphine and $20 \mathrm{~mol} \%$ 2,6-lutidine in a catalytic reaction of 11 and $\mathbf{1 2}$ does not give an appreciable quantity of 13a after $18 \mathrm{~h}$ at $80 \mathrm{C}$, indicating that the vinyl phosphine is not an active catalyst in the hydrosilylation reaction, and this is further supported by computational studies. ${ }^{34}$

Next, we undertook kinetic studies using NMR spectroscopic monitoring. By pre-forming the catalyst in situ, we have analyzed the order in substrates $\mathbf{1 1}$ and $\mathbf{1 2}$ by varying the amount of the starting material using $10 \mathrm{~mol} \% 3 \cdot \mathbf{B}_{\mathrm{Ar}}^{\mathrm{F}}$. The data obtained suggest first-order dependence in 11, while an inverse order is observed for $\mathbf{1 2}^{35}$ (Figure 3). Product inhibition is not observed, with similar reaction rates obtained when adding 0.5 equiv of product $13 \mathrm{a}$ to the catalytic reaction of 11 and 12 in a $1: 1$ mixture $\left(5.32 \times 10^{-4}\right.$ vs $5.63 \times 10^{-4}$ $\left.\mathrm{mmol} / \mathrm{dm}^{3} \mathrm{~min}\right)$. Therefore, the negative order in silane can be attributed to silane involvement in side-product formation or catalyst degradation. Comparable data are obtained when using isolated pre-catalyst $3 \cdot \mathbf{B}_{\mathrm{Ar}} \mathbf{F}$ in the absence of 2,6-lutidine, 
Scheme 2. ${ }^{29} \mathrm{Si}\left\{{ }^{1} \mathrm{H}\right\}$ and ${ }^{31} \mathrm{P}\left\{{ }^{1} \mathrm{H}\right\}$ NMR Spectroscopy Speciation Studies of (a) Standard Catalytic Reaction of 3・B ${ }_{\mathrm{Ar}}^{\mathrm{F}}$, 2,6Lutidine, 11, and 12; (b) Stoichiometric Reaction of $3 \cdot B_{A r}{ }_{A}^{F}, 2,6-$ Lutidine and 12; and (c) Stoichiometric Reaction of $3 \cdot B_{A r}{ }^{F}$, 2,6-Lutidine, 11, and 12

\section{Speciation studies}

a) Catalytic reaction mixture

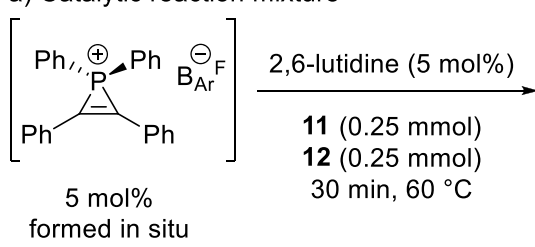

formed in situ

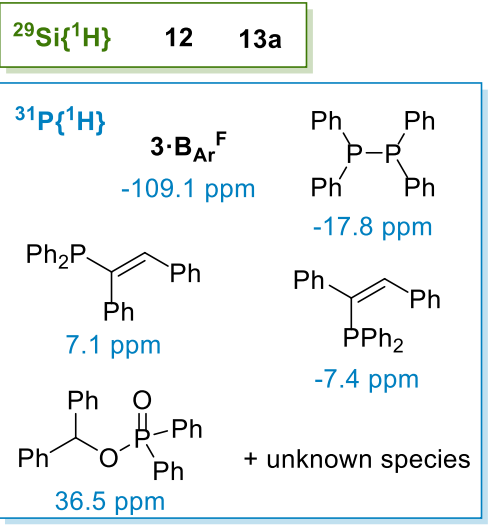

b) Stoichiometric reaction I

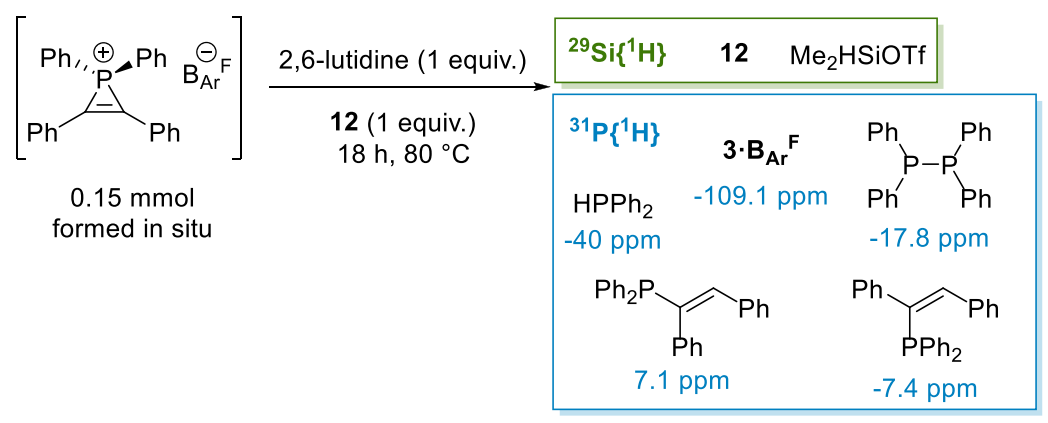

b) Stoichiometric reaction II

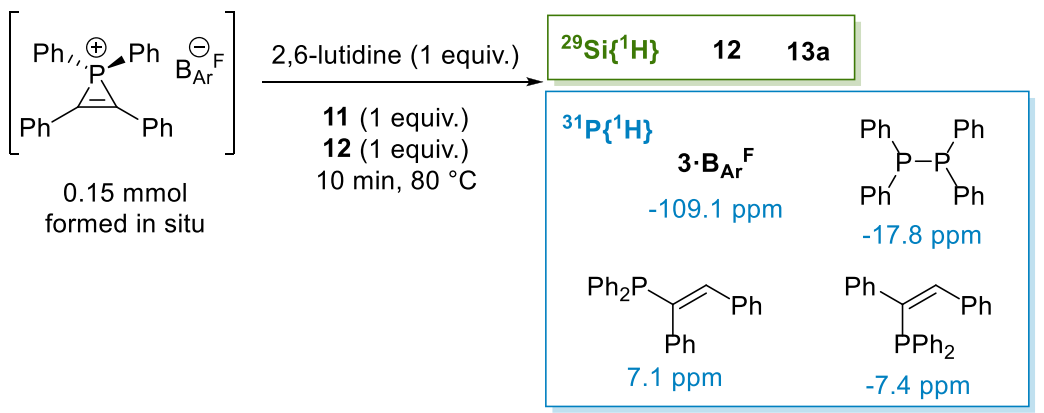

further supporting the assertion that the role of 2,6-lutidine is simply to mop up $\mathrm{TfOH}$ released on formation of $3 \cdot \mathbf{B}_{\mathrm{Ar}}{ }^{\mathrm{F}}$ from reaction of $\mathrm{Tf}_{2} \mathrm{O}$ with alkyne, SPO, and $\mathrm{NaB}_{\mathrm{Ar}}{ }^{\mathrm{F}} \cdot{ }^{26}$ It is important to note that the kinetic data found for this transformation are in contrast with Piers' hydrosilylation-type activation via Lewis acids $\left[\right.$ e.g., $\left.\mathrm{B}\left(\mathrm{C}_{6} \mathrm{~F}_{5}\right)_{3}\right]$, ${ }^{36}$ where the increase in ketone concentration slows down the reaction. Indeed, interrogating the ${ }^{11} \mathrm{~B}$ and ${ }^{19} \mathrm{~F}$ NMR spectra from catalytic reactions also shows that only borate is present in solution; no borane signals are observed, and so we feel that boranemediated hydrosilylation is unlikely in this case.

At this stage, we have three distinct pieces of experimental data that necessitate further investigation:

(i) Observation of vinyl phosphine both during catalysis and in stoichiometric studies indicates that phosphirenium ring opening could be involved, either as a catalyst deactivation process or on-cycle ring-opening/ringclosure sequence; (ii) The inverse order in silane indicates that there is a catalytically inactive pathway dominating at higher silane loadings.

(iii) Phosphirenium ions with different electronic substituents have very different capabilities in hydrosilylation (9. $\left.\mathbf{B}_{\mathrm{Ar}}^{\mathrm{F}}>3 \cdot \mathbf{B}_{\mathrm{Ar}}^{\mathrm{F}} \gg \mathbf{1 0} \cdot \mathbf{B}_{\mathrm{Ar}}^{\mathrm{F}}\right)$, but these changes in electronics only have a modest impact on the phosphorus center (e.g., compare 3.OTf, 9.OTf, and 10. OTf ${ }^{31} \mathrm{P}$ NMR chemical shift). We therefore believe that the role of the phosphirenium pre-catalyst is not merely to act as a simple Lewis acid.

With these experimental results in hand, we undertook a computational study of the reactions of the phosphirenium cation, $3^{+}$(denoted as $\mathbf{I}$ in the computational study) with acetone and $\mathrm{Me}_{2} \mathrm{PhSiH}$. Initial studies considered the direct nucleophilic attack of either the ketone or silane at the phosphirenium ring; ${ }^{29}$ however, the characterization of these processes indicated that a ring-opening step occurs first to form an ethenylium intermediate II at $+22.0 \mathrm{kcal} / \mathrm{mol}$. From 
a)

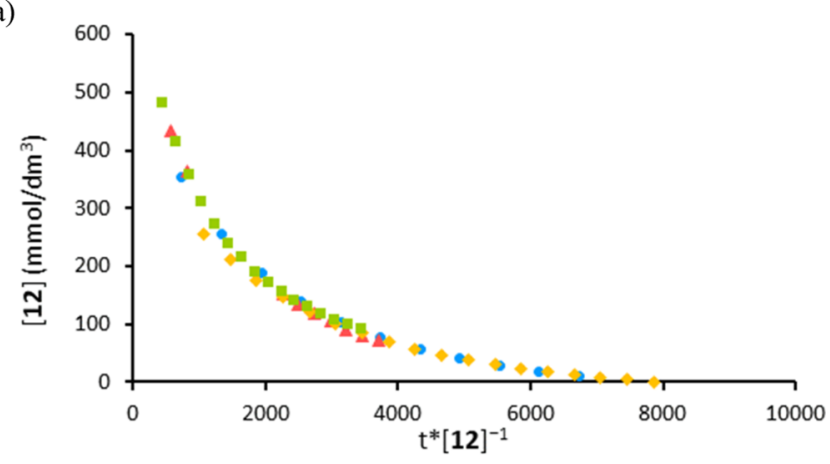

b)

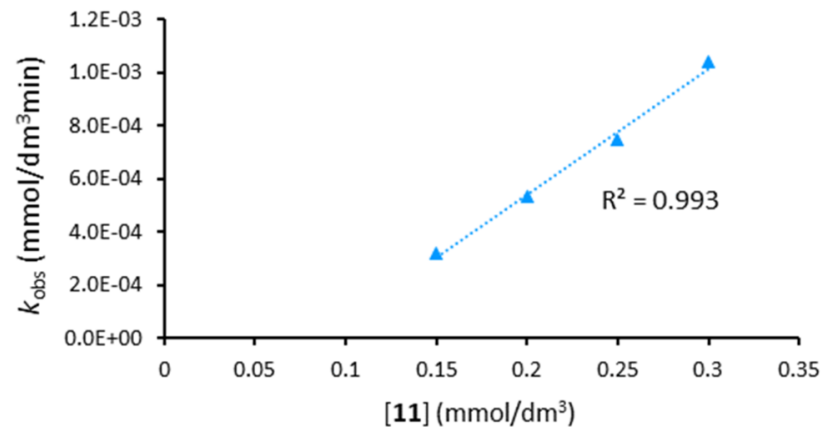

Figure 3. a) Graphical analysis showing inverse order relationship for the formation of $13 \mathrm{a}$ at different phenyldimethylsilane 12 loadings (yellow 0.75 , blue $\bigcirc$, red 1.25 , and green 1.5 equiv); (b) plot showing first-order dependence for the formation of 13a at different benzophenone 11 loadings $(0.75,1,1.25$, and 1.5 equiv); and reaction conditions: (i) activation step $\mathrm{Ph}_{2} \mathrm{P}(\mathrm{O}) \mathrm{H} 2(10 \mathrm{~mol} \%)$, $\mathrm{Tf}_{2} \mathrm{O}(10 \mathrm{~mol} \%), \mathrm{NaB}_{\mathrm{Ar}}^{\mathrm{F}}(10 \mathrm{~mol} \%)$, diphenylacetylene 1 (10 mol $\%), \mathrm{CD}_{3} \mathrm{CN}(0.4 \mathrm{M}), 60^{\circ} \mathrm{C}$, and $30 \mathrm{~min}$ and (ii) 2,6-lutidine (10 mol $\%)$, ketone or aldehyde $(0.20 \mathrm{mmol})$, silane $(0.20 \mathrm{mmol}), 80^{\circ} \mathrm{C}$, and $\mathrm{PhMe}$ used as an internal standard.

II, catalysis is initiated via the nucleophilic attack of the ketone at the $\mathrm{P}$ center (see Figure 4a). This proceeds through TS(IIIII) $)_{\mathrm{p}}$ at $+28.6 \mathrm{kcal} / \mathrm{mol}$ and results in both $\mathrm{P}-\mathrm{O}$ bond formation and displacement of the alkyne to form a phosphenium-ketone adduct III $_{\mathbf{P}}$. Catalysis now proceeds (Figure $4 \mathrm{~b}$ ) via $\mathrm{Si}-\mathrm{H}$ addition across the $\mathrm{C}=\mathrm{O}$ moiety [TS $\left.(\mathbf{I I I}-\mathbf{I V})_{\mathrm{P}},+27.9 \mathrm{kcal} / \mathrm{mol}\right]$ to form $\mathbf{I V}_{\mathbf{P}}$, in which partial hydride transfer has occurred $(\mathrm{C} \cdots \mathrm{H}=1.29 \AA$; $\mathrm{H} \cdots \mathrm{Si}=1.71$ $\AA$ ). Silyl group migration then readily occurs to form $\mathbf{V}_{\mathbf{P}}$ at $-7.8 \mathrm{kcal} / \mathrm{mol}$, featuring a silylalkyloxonium adduct of the $\left\{\mathrm{Ph}_{2} \mathrm{P}\right\}$ moiety. Ketone attack at $\mathbf{V}_{\mathbf{P}}$ then displaces the hydrosilylation product and generates III $_{\mathbf{P}}$ that can then enter a second cycle with further reaction with silane. ${ }^{38}$

Overall, the calculations imply a relatively slow initiation process via $\mathbf{T S}(\mathrm{II}-\mathrm{III})_{\mathbf{P}}$ at $28.6 \mathrm{kcal} / \mathrm{mol}$ to form III $_{\mathbf{P}}$, from which catalysis can then proceed with an energy span of only $10.8 \mathrm{kcal} / \mathrm{mol}$. Catalysis from III $_{\mathbf{P}}$ should therefore be very efficient; however, the situation is complicated by at least two possible competing reactions. The first of these is vinyl phosphine formation (Figure 4c). This involves silane attack at the $\mathrm{C} 1$ position of intermediate II and proceeds via TS(IIIII $)_{\mathrm{H}}$ at $+30.7 \mathrm{kcal} / \mathrm{mol}$ with net insertion into the $\mathrm{Si}-\mathrm{H}$ bond to give silylalkylphosphonium ion $\mathrm{III}_{\mathrm{H}, \mathrm{Z}}$ at $-9.0 \mathrm{kcal} / \mathrm{mol}$, featuring a short $\mathrm{P}-\mathrm{C}$ bond $(1.76 \AA)$. Assuming facile rotation about the $\mathrm{C}-\mathrm{C}$ bond leads to $\mathrm{III}_{\mathrm{H}, \mathrm{E}}(-7.3 \mathrm{kcal} / \mathrm{mol})$, which can react with ketone with displacement of a silylether cation to form $E$-vinyl phosphine $\mathbf{I V}_{\mathrm{H}, \mathrm{E}}(-33.3 \mathrm{kcal} / \mathrm{mol}) .{ }^{39} \mathrm{In}$ principle, $\mathbf{I V}_{\mathrm{H}, \mathrm{E}}$ could re-enter catalysis via hydride transfer to the silylether cation, generating the hydrosilylation product and intermediate II. However, this process has a computed barrier of $48.3 \mathrm{kcal} / \mathrm{mol}$, and so the formation of vinyl phosphine represents an unproductive off-cycle process. The second competing process (Figure $4 \mathrm{~d}$ ) involves the reaction of $\mathbf{V}_{\mathbf{P}}$ with alkyne via $\mathbf{T S}(\mathbf{V}-\mathbf{I I})_{\mathbf{P}}$ at $+3.3 \mathrm{kcal} / \mathrm{mol}$ with the release of the hydrosilylation product and formation of II. II can then rapidly undergo ring closure to reform $\mathbf{I}$.

The significance of these two competing processes is captured in the free energy differences $(\Delta \Delta G)$ between the rate-limiting transition states. For vinyl phosphine formation, these are $\mathbf{T S}(\mathbf{I I}-\mathbf{I I I})_{\mathrm{H}}$ and $\mathbf{T S}(\mathbf{I I}-\mathbf{I I I})_{\mathrm{P}}$, where the latter is more stable and $\Delta \Delta \mathrm{G}_{1}=+2.1 \mathrm{kcal} / \mathrm{mol}$. The productive onward reaction to form III $_{\mathbf{p}}$ should therefore dominate; however, the small energy difference suggests that vinyl phosphine formation may be significant at higher silane concentrations, and this is consistent with the experimental identification of an inverse first-order reaction with respect to silane. For the competing reactions of $\mathbf{V}_{\mathbf{p}}$ with either the ketone or the alkyne, the key transition states are TS $(\text { III-IV })_{P}$ and $\mathbf{T S}(\mathbf{V}-\mathrm{II})_{\mathbf{P}}$, respectively. In this case, $\mathbf{T S}(\mathrm{V}-\mathrm{II})_{\mathrm{P}}$ is only marginally disfavored with $\Delta \Delta \mathrm{G}_{2}=+0.4 \mathrm{kcal} / \mathrm{mol}$, and this small energy difference suggests reaction with alkyne and therefore the reformation of $\mathbf{I}$ will be competitive. However, unlike the vinyl phosphine $\mathbf{I V}_{\mathrm{E}}$, I remains a competent catalyst precursor, albeit one that reacts with a relatively high overall barrier of $28.6 \mathrm{kcal} / \mathrm{mol}$. There is therefore an ensemble of processes at play, in which efficient catalysis via III $_{\mathbf{P}}$ is balanced by catalyst loss through vinyl phosphine formation and a less efficient cycle based on phosphirenium precursor I. The net effect of these various processes is qualitatively consistent with a reaction that requires several hours at $60{ }^{\circ} \mathrm{C}$ to reach full conversion.

2.3.1. Substituent Effects. Reaction profiles computed for cations $\mathbf{9}^{+}$and $\mathbf{1 0}^{+}$were similar to those for the parent species $3^{+}$(see the Supporting Information). However, subtle changes in the relative energies of the key competing transition states are computed that have a significant impact on the behavior of these systems (see Figure 5). For $\mathbf{9}^{+}$, the electron-withdrawing $p-\mathrm{CF}_{3}$ substituents cause an increase in both $\Delta \Delta \mathrm{G}_{1}$ and $\Delta \Delta \mathrm{G}_{2}$. As a result, catalysis becomes more efficient both in terms of a reduced likelihood of vinyl phosphine formation and a lower propensity to reform the phosphirenium cation. This is reflected in the short (ca. $1 \mathrm{~h}$ ) times to full conversion seen experimentally with $\mathbf{9}^{+}$. In contrast, the electron-donating $p$ OMe substituents switch the preference toward vinyl phosphine formation from II $\left(\Delta \Delta \mathrm{G}_{1}=-1.8 \mathrm{kcal} / \mathrm{mol}\right)$ and favoring the reaction of $\mathbf{V}_{\mathbf{P}}$ with alkyne that leads to the formation of $\mathbf{I}$ over the more direct catalytic reaction with ketone. Both factors should render catalysis less efficient, consistent with the very sluggish catalytic reaction that is observed with $\mathbf{1 0}^{+}$( $58 \mathrm{~h}$ to full conversion). The calculations indicate that while the $p$-OMe substituents in $\mathbf{1 0}^{+}$promote ring opening $\left[\Delta \mathrm{G}_{\mathrm{I} \rightarrow \mathrm{II}}=+17.6 \mathrm{kcal} / \mathrm{mol}(p-\mathrm{OMe}),+22.0 \mathrm{kcal} / \mathrm{mol}\right.$ $(p-\mathrm{H})$, and $\left.+24.1 \mathrm{kcal} / \mathrm{mol}\left(p-\mathrm{CF}_{3}\right)\right]$, they also disfavor the subsequent $\left\{\mathrm{Ph}_{2} \mathrm{P}^{+}\right\}$transfer via TS(II-III) $)_{\mathrm{P}}$, and this results in hydride transfer via TS(II-III $)_{\mathrm{H}}$ dominating.

These combined experimental and computational studies allow us to propose a reaction mechanism for the hydrosilylation of carbonyls catalyzed by phosphirenium cations. These species act as a masked phosphenium source that is accessed via ring opening. Productive turnover then involves 
(b) Catalysis

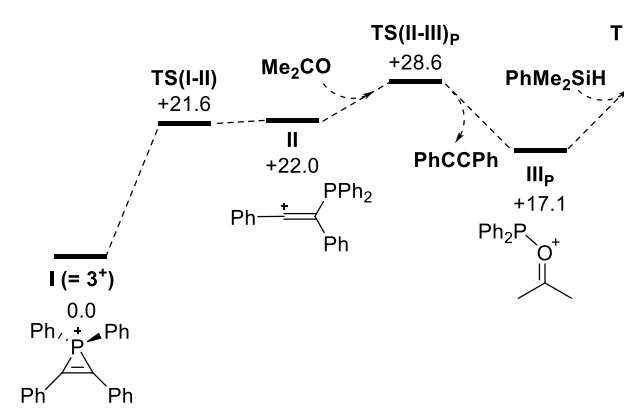

(c) Vinyl Phosphine Formation

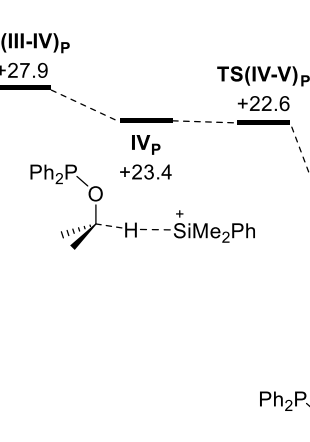

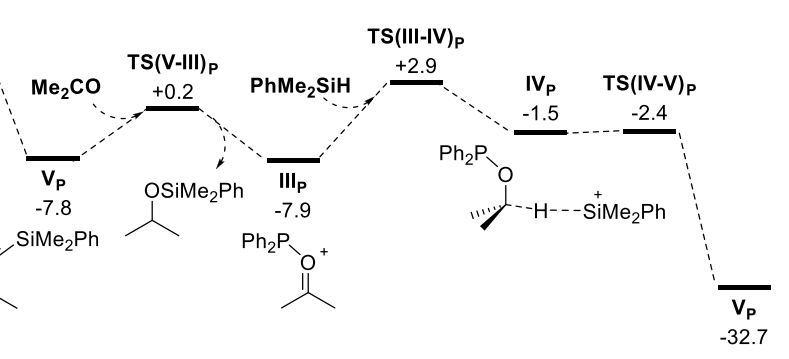

(d) Phosphirenium Reformation

$$
\mathrm{Ph}_{2} \mathrm{P}_{\mathrm{O}_{+}}-\mathrm{SiMe}_{2} \mathrm{Ph}
$$

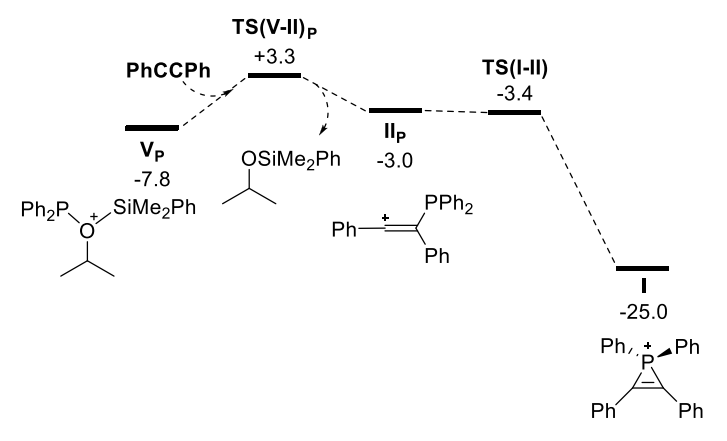

Figure 4. Free energy reaction profiles $(\mathrm{kcal} / \mathrm{mol})$ for the reactions of $\mathrm{Me}_{2} \mathrm{PhSiH}$ with acetone mediated by the phosphirenium cation $3^{+}$computed at the M052X-D3 $\left(\mathrm{CH}_{3} \mathrm{CN}\right) /$ def2-TZVP//TPSS/def2-SVP level of theory. (a) Initiation via ketone attack at $\mathrm{P}$ in the ring-opened ethenylium cation, II; (b) catalytic cycle based on intermediate III $_{p} ;(c)$ competing vinyl phosphine formation; and (d) competing phosphirenium reformation.

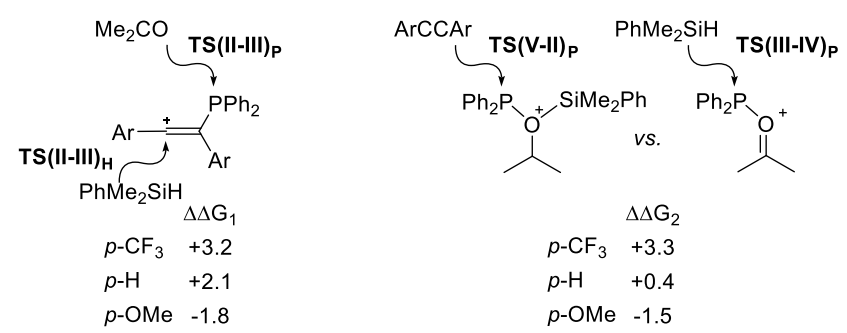

Figure 5. Comparison of key transition states (free energies, kcal/ $\mathrm{mol})$ for the competing processes outlined in Figure 4. $\Delta \Delta \mathrm{G}_{1}=$ TS $(\text { II-III })_{\mathrm{H}}-$ TS $(\text { II-III })_{\mathrm{P}}$ and $\Delta \Delta \mathrm{G}_{2}=$ TS $(\text { V-II })_{\mathrm{P}}-$ TS $(\mathrm{III}-$ $\mathrm{IV})_{\mathbf{P}}$.

associative phosphenium transfer to the ketone, $\mathrm{Si}-\mathrm{H}$ addition over the $\mathrm{C}=\mathrm{O}$ bond, and associative displacement of the hydrosilylation product with further ketone. Spectroscopic and computational insights show that the formation of vinyl phosphine is an irreversible off-cycle process that will sequester the $\left\{\mathrm{Ph}_{2} \mathrm{P}^{+}\right\}$moiety through reaction with silane, in accordance with inverse order kinetics. Para-substituents on the phosphirenium aryl groups can significantly impact the behavior; electron-donating $p$-OMe substituents undermine catalysis by favoring the formation of side products.

Experimentally, the observation of $\mathrm{HPPh}_{2}$ and $\mathrm{P}_{2} \mathrm{Ph}_{4}$ by in situ reaction monitoring also supports the presence of the ring- opened form in the catalytic reaction. Given the capricious nature of unstabilized phosphenium ions, we do not observe free $\left\{\mathrm{Ph}_{2} \mathrm{P}^{+}\right\}$in the catalytic reaction. Calculations indicate that loss of $\left\{\mathrm{Ph}_{2} \mathrm{P}^{+}\right\}$from the parent phosphirenium is uphill by 34 $\mathrm{kcal} / \mathrm{mol}$; thus, observation of the free species is unlikely, lending further support to it being transferred directly between nucleophiles during the cycle. Catalytic reactions do show the presence of a phosphinate peak in the ${ }^{31} \mathrm{P}$ NMR spectrum (-36.5 ppm, corresponding to benzhydryl diphenyl phosphinate $^{31}$ ), which gives tentative support for the presence of phosphenium adducts.

2.4. Hydrosilylation Substrate Scope. With the optimal conditions for catalytic hydrosilylation and choosing to use commercially available diphenyl acetylene for in situ precatalyst formation (Table 2, entry 6), we explored the generality of the reaction. Compound 13a can be isolated in $73 \%$ yield, after $5 \mathrm{~h}$ at $60{ }^{\circ} \mathrm{C}$ using $2.5 \mathrm{~mol} \% 3 \cdot \mathbf{B}_{\mathrm{Ar}}^{\mathrm{F}}$ (Figure 6). Aryl-substituted ketones react well under the reaction conditions, giving 13b-13d in excellent 83-97\% isolated yields. Electron-withdrawing and electron-donating groups in the para-position are well tolerated. These results are interesting because diaryl ketones have been reported to typically react to yield fully deoxygenated products when subjected to higher temperatures or longer reaction times. ${ }^{40}$

In this procedure, the higher temperature does not affect the reaction outcome with hydrosilylation of diaryl ketones 


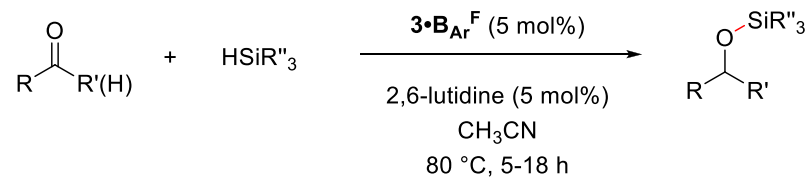

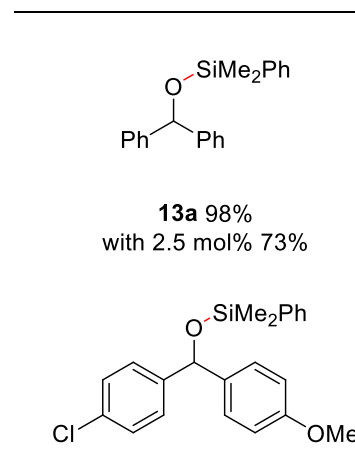

$13 d 83 \%$<smiles>CCOC(c1ccccc1)c1ccc(Cl)cc1</smiles>

13b $97 \%$<smiles>Cc1ccc(C(O[SiH2]c2ccccc2)c2ccc(Cl)cc2)cc1</smiles>

13c $88 \%$<smiles>Cc1ccccc1C(C)O[SiH2]c1ccccc1</smiles>

13 e $77 \%$<smiles>CC(OC(/C=C/c1ccccc1)c1ccccc1)c1ccccc1</smiles>

$13 f 80 \% 4: 1$<smiles>c1ccc(OCCOC2CCCCC2)cc1</smiles>

$13 g 87 \%^{b}$<smiles>CC(C)O[AsH2]c1ccccc1</smiles>

13h $62 \%^{\mathrm{b}}$<smiles>CC[SiH2]OC(c1ccccc1)c1ccccc1</smiles>

$13 \mathrm{i} 23 \%^{\mathrm{b}}$ 13j $85 \%$<smiles>Fc1ccc(CO[SiH2]c2ccc([SeH2])cc2)cc1</smiles><smiles>Cc1ccc(CO[SiH2]c2ccccc2)cc1</smiles>

13o $74 \%$

$13 p$ 60\%

$13 q 75 \%$

13r $89 \%$<smiles>CN(C)c1ccc(COSc2ccccc2)cc1</smiles>

13s $22 \%$ a,b<smiles>OCCOCc1ccccc1Br</smiles>

13t $50 \%{ }^{b}$<smiles>O=[N+]([O-])c1ccccc1COCCO</smiles>

$13 \mathrm{u} 43 \%^{\mathrm{b}}$<smiles>Brc1cccc(COc2ccccc2)c1</smiles>

13v $30 \%^{b}$

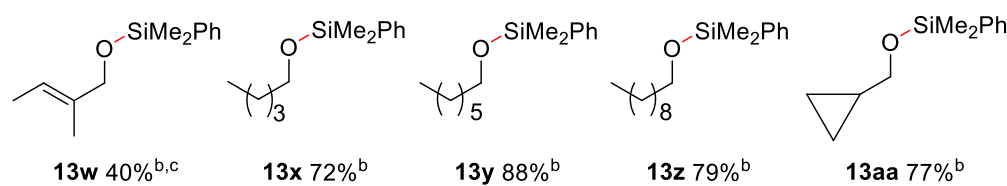

Figure 6. Reaction conditions: (i) activation step $\mathrm{Ph}_{2} \mathrm{P}(\mathrm{O}) \mathrm{H} 2$ (5 mol \%), $\mathrm{Tf}_{2} \mathrm{O}$ (5 mol \%), $\mathrm{NaB}_{\mathrm{Ar}}{ }^{\mathrm{F}}(5 \mathrm{~mol} \%)$, diphenylacetylene 1 (5 mol \%), $\mathrm{CD}_{3} \mathrm{CN}(0.41 \mathrm{M}), 6{ }^{\circ} \mathrm{C}$, and $30 \mathrm{~min}$ and (ii) 2,6-lutidine $(5 \mathrm{~mol} \%)$, ketone or aldehyde $(0.25 \mathrm{mmol})$, silane $(0.25 \mathrm{mmol}), 80{ }^{\circ} \mathrm{C}$, and $5 \mathrm{~h}$, reported as an average of two runs; ${ }^{\mathrm{a}}$ conversion; ${ }^{\mathrm{b}} 10 \mathrm{~mol} \%, 18 \mathrm{~h}$; ${ }^{\mathrm{c}}$ spectroscopic yield.

occurring selectively in $5 \mathrm{~h}$. Unsymmetrical ketones with an aryl substituent and $\mathrm{C}_{\mathrm{sp}}{ }^{3}$ and $\mathrm{C}_{\mathrm{sp}}{ }^{2}$ substituents yield $13 \mathrm{e}$ and $13 \mathrm{f}$ in full conversion ( 77 and $80 \%$ isolated yields, respectively). Alkyne-containing carbonyl substrates are not suitable for this transformation, possibly due to alkyne scrambling of the propargyl group. ${ }^{41}$ Cyclohexanone and acetone react well using $10 \mathrm{~mol} \% 3 \cdot \mathrm{B}_{\mathrm{Ar}}^{\mathrm{F}}$, giving $13 \mathrm{~g}$ and $13 \mathrm{~h}$ in 87 and $62 \%$ yields, respectively, while acetophenone reacts sluggishly, and even with $10 \mathrm{~mol} \%$ catalyst loading, only $23 \%$ of 13i is obtained. The use of other tertiary silanes was found to be suitable, and $\mathbf{1 3} \mathbf{j}$ is obtained in full conversion and high yield (85\%). However, triethoxy silane and triphenyl silane do 
not convert, but the phosphirenium pre-catalyst is unaffected and is still observed in the reaction mixture. Secondary or primary silanes do not react with benzophenone $\mathbf{1 1}$ under the reaction conditions, and decomposition of the phosphirenium is observed by NMR spectroscopy.

Several aldehydes were subjected to the optimized reaction conditions, and the results are good to excellent when using electron-poor aryl aldehydes, with $60-98 \%$ isolated yields for $13 k-13 p$. Cinnamaldehyde reacts smoothly to yield $13 q$ in $75 \%$ yield. The reaction also works well with 4-methylbenzaldehyde, furnishing $13 \mathbf{r}$ in $89 \%$ isolated yield, but is quite limited with other electron-rich aldehydes. 4-Dimethylamino benzaldehyde shows low conversion into 13 s $(22 \%)$ after $18 \mathrm{~h}$ with $10 \mathrm{~mol} \% 3 \cdot \mathbf{B}_{\mathrm{Ar}}{ }^{\mathrm{F}}$; 4-methoxybenzaldehyde does not show any conversion after $24 \mathrm{~h}$, which suggests a potential deactivation of the carbonyl or catalyst poisoning. Electronwithdrawing groups in the ortho- and meta-position are detrimental, giving low conversion and yield of $13 \mathbf{t}, \mathbf{1 3} \mathbf{u}$, and 13v. Tiglic aldehyde reacts using $10 \mathrm{~mol} \%$ catalyst at $80{ }^{\circ} \mathrm{C}$ with full conversion of silane to $13 \mathrm{w}$ in only $40 \%$ spectroscopic yield, with traces of the product derived from the reduction of the double bond observed in situ. Alkyl aldehydes such as pentanal, heptanal, and dodecanal give 13x, 13y, and $13 \mathrm{z}$ in $72-88 \%$ isolated yields, respectively, and cyclopropane aldehyde reacts to give 13 aa in $77 \%$ isolated yield with no ring opening observed, highlighting that radicals are not involved in the reaction.

\section{CONCLUSIONS}

The ease of synthesis and the newly discovered reactivity of phosphirenium ions allow us to conclude that they are effective organocatalysts for the hydrosilylation of ketones and aldehydes; to the best of our knowledge, this is the first report of a phosphirenium ion being used as a pre-catalyst. Full characterization of the phosphirenium ions bearing triflate or borate counterions is reported, and further details on their synthesis were explored. The practical pre-catalyst synthesis from typically cheap and readily available starting materials such as phosphine oxides and alkynes allows a straightforward catalytic procedure that is easily scalable. Our mechanistic investigations give insights into the principles governing their reactivity; this is underpinned by DFT studies and experimentally determined kinetics and stoichiometric studies. The ability of these phosphirenium ions to undergo ring opening paves the way for several reaction pathways, with the dominant and most favorable pathway being the release of the active catalyst, which is a phosphenium ion adduct. Increasing the electron-donating ability of the alkyne used to prepare the pre-catalyst slows catalysis, allowing an off-cycle deactivation process to dominate. These elusive phosphenium species are highly reactive and challenging to isolate and characterize; therefore, by disguising a phosphenium catalyst as a more stable and manageable phosphirenium adduct, we open up a multitude of opportunities in organic synthesis. Work is still ongoing in our laboratory to shed light on diverse reactivity and the activation modes of phosphirenium rings and the broader applicability of masked phosphenium catalysts.

\section{EXPERIMENTAL SECTION}

4.1. General Procedure for Synthesis of Phosphirenium lons. In a J-Young NMR tube or a Schlenk tube, alkyne $(0.25 \mathrm{mmol})$, SPO $(0.25 \mathrm{mmol})$, triflic anhydride (1 equiv.), and $\mathrm{NaB}_{\mathrm{Ar}}{ }^{\mathrm{F}}$ (1 equiv.) were stirred in $\mathrm{CD}_{3} \mathrm{CN}$ or $\mathrm{CDCl}_{3}$ at 60 ${ }^{\circ} \mathrm{C}$ for $30 \mathrm{~min}$. The reaction was monitored by ${ }^{31} \mathrm{P}\left\{{ }^{1} \mathrm{H}\right\} \mathrm{NMR}$ spectroscopy until complete disappearance of the phosphine oxide peak. After the reaction was completed, the mixture was concentrated under vacuum. The product was washed with pentane and recrystallized at $-20{ }^{\circ} \mathrm{C}$.

4.2. General Procedure for the Hydrosilylation of Ketones and Aldehydes. To a J-Young NMR tube, dicyclohexyl phosphine oxide $\left(5 \mathrm{~mol} \%, 12.5 \times 10^{-3} \mathrm{mmol}\right.$, $2.7 \mathrm{mg}$ ) or diphenyl phosphine oxide ( $5 \mathrm{~mol} \%, 12.5 \times 10^{-3}$ or $\left.25 \times 10^{-3} \mathrm{mmol}, 2.5 \mathrm{mg}\right)$, diphenylacetylene $(5 \mathrm{~mol} \%, 12.5 \times$ $\left.10^{-3} \mathrm{mmol}, 2.3 \mathrm{mg}\right)$, triflic anhydride $\left(5 \mathrm{~mol} \%, 12.5 \times 10^{-3}\right.$ mmol, $2.1 \mu \mathrm{L}$ ), and $\mathrm{NaB}_{\mathrm{Ar}}^{\mathrm{F}}\left(5 \mathrm{~mol} \%, 12.5 \times 10^{-3} \mathrm{mmol}, 11.1\right.$ $\mathrm{mg}$ ) were stirred in $\mathrm{CH}_{3} \mathrm{CN}(3 \mathrm{~mL})$ for $30 \mathrm{~min}$ at $60{ }^{\circ} \mathrm{C}$. After formation of pre-catalyst $3 \cdot \mathbf{B}_{\mathrm{Ar}}^{\mathrm{F}}$, the reaction mixture was cooled down, and 2,6-lutidine ( $5 \mathrm{~mol} \%, 12.5 \times 10^{-3} \mathrm{mmol}$, $1.5 \mu \mathrm{L})$, benzophenone $(0.25 \mathrm{mmol}, 45.5 \mathrm{mg})$, and dimethylphenylsilane $(0.25 \mathrm{mmol}, 38.3 \mu \mathrm{L})$ were added, and the reaction was heated at 80 or $60{ }^{\circ} \mathrm{C}$ for 18 and $5 \mathrm{~h}$, respectively. After drying the volatiles, the pure product was obtained by purification by flash chromatography (9:1 petroleum ether/EtOAc) or vacuum distillation.

4.3. DFT Calculations. Gaussian 09 (Revision D.01) was used with geometry optimizations carried out at the TPSS/ def2-SVP level and all stationary points characterized with analytical frequency calculations. Electronic energies were recomputed at the M052X-D3 $\left(\mathrm{CH}_{3} \mathrm{CN}\right) / \mathrm{def} 2-\mathrm{TZVP}$ level, which has been shown to be a reliable approach for main group kinetics, thermodynamics, and non-covalent interactions. ${ }^{42}$ These corrected energies were then combined with the thermodynamic corrections from the gas-phase calculations to give the free energies quoted in the text. Full details and references are supplied in the Supporting Information.

\section{ASSOCIATED CONTENT}

Supporting Information

The Supporting Information is available free of charge at https://pubs.acs.org/doi/10.1021/acscatal.1c01133.

Analysis data and NMR spectra for all products and computational supporting information which contains all data relevant to the computational studies reported here, including methodology, references, benchmarking studies, energetics, and coordinates of characterized stationary points (CIF)

General considerations, synthesis and characterization of the starting material, synthesis of phosphirenium ions, substrate scope hydrosilylation, and optimization of the catalytic reaction (PDF)

Computed geometries for all stationary points (XYZ)

\section{AUTHOR INFORMATION}

\section{Corresponding Authors}

Stuart A. Macgregor - Institute of Chemical Sciences, HeriotWatt University, Edinburgh EH14 4AS, U.K.; $\odot$ orcid.org/ 0000-0003-3454-6776; Email: S.A.Macgregor@hw.ac.uk

Ruth L. Webster - Department of Chemistry, University of Bath, Bath BA2 7AY, U.K.; @ orcid.org/0000-0001-91997579; Email: R.L.Webster@bath.ac.uk

\section{Authors}

Danila Gasperini - Department of Chemistry, University of Bath, Bath BA2 7AY, U.K. 
Samuel E. Neale - Institute of Chemical Sciences, Heriot-Watt University, Edinburgh EH14 4AS, U.K.

Mary F. Mahon - Department of Chemistry, University of Bath, Bath BA2 7AY, U.K.

Complete contact information is available at: https://pubs.acs.org/10.1021/acscatal.1c01133

\section{Author Contributions}

The manuscript was written through contributions of all authors. All authors have given approval to the final version of the manuscript.

\section{Notes}

The authors declare no competing financial interest.

\section{ACKNOWLEDGMENTS}

The EPSRC is thanked for funding. S.E.N. thanks Heriot Watt University for the award of a James Watt scholarship.

\section{REFERENCES}

(1) (a) Mathey, F. Chemistry of 3-Membered Carbon-Phosphorus Heterocycles. Chem. Rev. 1990, 90, 997-1025. (b) Regitz, M. A. W.; Bergsträßer, U.; Black, D. StC.; Heydt, H.; König, B.; Maas, G.; Mathey, F.; Regitz, M.; Schatz, J.; Tokitoh, N.; Zeller, K.-P. Product Class 6: Phosphirenes. In Category 2, Hetarenes and Related Ring Systems; Maas, G., Ed.; Georg Thieme Verlag: Stuttgart, 2001; Vol. 9.

(2) (a) Breslow, R. Antiaromaticity. Acc. Chem. Res. 1973, 6, 393398. (b) Gonbeau, D.; Pfister-Guillouzo, G. Application of Photoelectron Spectroscopy to Molecular Properties. 25. Stabilization of Phosphinidene and Phosphirene by Complexation on Phosphorus. Theoretical Studies and Photoelectron Spectra. Inorg. Chem. 1985, 24, 4133-4140. (c) Göller, A.; Heydt, H.; Clark, T. $\sigma^{*}$-Aromaticity of Substituted 1h-Phosphirenium Cations and Substituted Silacyclopropenes. J. Org. Chem. 1996, 61, 5840-5846. (d) Priyakumari, C. P.; Jemmis, E. D. $\mathrm{P}_{3} \mathrm{~F}_{9}{ }^{2-}$ : An All-Pseudo- $\pi^{*} 2 \pi$-Aromatic. J. Am. Chem. Soc. 2013, 135, 16026-16029.

(3) Marinetti, A.; Mathey, F.; Fischer, J.; Mitschler, A. Generation and Trapping of Terminal Phosphinidene Complexes. Synthesis and X-Ray Crystal Structure of Stable Phosphirene Complexes. J. Am. Chem. Soc. 1982, 104, 4484-4485.

(4) (a) Fongers, K. S.; Hogeveen, H.; Kingma, R. F. Synthesis of Phosphirenium Salts. Tetrahedron Lett. 1983, 24, 643-646. (b) Breslow, R.; Deuring, L. A. Concerning Phosphirenium Cations. Tetrahedron Lett. 1984, 25, 1345-1348.

(5) Weissman, S. A.; Baxter, S. G. Evidence for the Rearrangement of P-Chloro-Phosphirenium Ions to P-Vinyl-Phosphenium Ions. Tetrahedron Lett. 1990, 31, 819-822.

(6) Hockless, D. C. R.; McDonald, M. A.; Pabel, M.; Wild, S. B. 1Methyl-1-Phenylphosphiranium Triflate: Synthesis, Structure and Reactivity. J. Chem. Soc., Chem. Commun. 1995, 257-258.

(7) Hockless, D. C. R.; McDonald, M. A.; Pabel, M.; Wild, S. B. Facile Syntheses and Interconversions between Simple Phosphiranium and Phosphirenium Salts. J. Organomet. Chem. 1997, 529, 189196.

(8) (a) Ekkert, O.; Kehr, G.; Fröhlich, R.; Erker, G. PhosphireniumBorate Zwitterion: Formation in the 1,1-Carboboration Reaction of Phosphinylalkynes. Chem. Commun. 2011, 47, 10482-10484. (b) Ueno, A.; Möricke, J.; Daniliuc, C. G.; Kehr, G.; Erker, G. Phosphirenium Borate Betaines from Alkynylphosphanes and the Halogeno- $\mathrm{B}\left(\mathrm{C}_{6} \mathrm{~F}_{5}\right)_{2}$ Reagents. Chem. Commun. 2018, 54, 1374613749 .

(9) Unoh, Y.; Hirano, K.; Miura, M. Metal-Free Electrophilic Phosphination/Cyclization of Alkynes. J. Am. Chem. Soc. 2017, 139, 6106-6109.

(10) (a) Nishimura, K.; Hirano, K.; Miura, M. Synthesis of Dibenzophospholes by $\mathrm{Tf}_{2} \mathrm{O}$-Mediated Intramolecular PhosphaFriedel-Crafts-Type Reaction. Org. Lett. 2019, 21, 1467-1470. (b) Nishimura, K.; Hirano, K.; Miura, M. Direct Synthesis of Dibenzophospholes from Biaryls by Double C-P Bond Formation Via Phosphenium Dication Equivalents. Org. Lett. 2020, 22, 31853189.

(11) Nishimura, K.; Unoh, Y.; Hirano, K.; Miura, M. PhospheniumCation-Mediated Formal Cycloaddition Approach to Benzophospholes. Chem.-Eur. J. 2018, 24, 13089-13092.

(12) (a) Huang, H.; Ash, J.; Kang, J. Y. Tf 2 O-Promoted Activating Strategy of Phosphate Analogues: Synthesis of Mixed Phosphates and Phosphinate. Org. Lett. 2018, 20, 4938-4941. (b) Yuan, T.; Huang, S.; Cai, C.; Lu, G.-p. Metal-Free Electrophilic Phosphination of Electron-Rich Arenes, Arenols and Aromatic Thiols with Diarylphosphine Oxides. Org. Biomol. Chem. 2018, 16, 30-33.

(13) (a) Cowley, A. H.; Kemp, R. A. Synthesis and Reaction Chemistry of Stable Two-Coordinate Phosphorus Cations (Phosphenium Ions). Chem. Rev. 1985, 85, 367-382. (b) Rosenberg, L. Metal Complexes of Planar $\mathrm{PR}_{2}$ Ligands: Examining the Carbene Analogy. Coord. Chem. Rev. 2012, 256, 606-626.

(14) (a) Nesterov, V.; Reiter, D.; Bag, P.; Frisch, P.; Holzner, R.; Porzelt, A.; Inoue, S. NHCs in Main Group Chemistry. Chem. Rev. 2018, 118, 9678-9842. (b) Speed, A. W. H. Applications of Diazaphospholene Hydrides in Chemical Catalysis. Chem. Soc. Rev. 2020, 49, 8335-8353.

(15) (a) Yang, C.-H.; Fan, H.; Li, H.; Hou, S.; Sun, X.; Luo, D.; Zhang, Y.; Yang, Z.; Chang, J. Direct Access to Allenylphosphine Oxides Via a Metal Free Coupling of Propargylic Substrates with $\mathrm{P}(\mathrm{O}) \mathrm{H}$ Compounds. Org. Lett. 2019, 21, 9438-9441. (b) Wang, J.; Deng, Y.-J.; Yan, X.-X.; Liu, Y.-J.; Ge, C.-P.; Yan, Y.; Chao, S.; Zhou, P.-X. Synthesis of 3-Phosphinoylbenzofurans Via Electrophilic Phosphination Cyclization. Org. Chem. Front. 2020, 7, 715-722.

(16) Li, C.; Wang, Q.; Zhang, J.-Q.; Ye, J.; Xie, J.; Xu, Q.; Han, L.-B. Water Determines the Products: An Unexpected Brønsted AcidCatalyzed PO-R Cleavage of $\mathrm{P}(\mathrm{III})$ Esters Selectively Producing $\mathrm{P}(\mathrm{O})-\mathrm{H}$ and $\mathrm{P}(\mathrm{O})-\mathrm{R}$ Compounds. Green Chem. 2019, 21, 29162922.

(17) Ivanov, B. E.; Krokhina, S. S.; Chichkanova, T. V.; Ageeva, A. B. Dual Reactivity of Diphenylphosphinous and Phenylphosphonous Acid Amides in Reactions with N-Acetoxymethyl-Substituted Diethylamine, Benzamide, and Acetamide. Bull. Acad. Sci. USSR, Div. Chem. Sci. 1986, 35, 2535-2539.

(18) Fluck, E.; Binder, H. Darstellung Von Verbindungen Mit P-P - Und P-P-P - Gerüsten. Inorg. Nucl. Chem. Lett. 1967, 3, 307313.

(19) See Supporting Information for further details.

(20) Gudat, D. Cationic Low Coordinated Phosphorus Compounds as Ligands: Recent Developments. Coord. Chem. Rev. 1997, 163, 71106.

(21) Vural, J. M.; Weissman, S. A.; Baxter, S. G.; Cowley, A. H.; Nunn, C. M. X-Ray Crystal Structure of a Phosphirenium Ion. J. Chem. Soc., Chem. Commun. 1988, 462-463.

(22) Marinetti, A.; Mathey, F. The Chemistry of Free and Complexed Phosphirenes: Reactivity toward Electrophiles, Nucleophiles, and Conjugated Dienes. J. Am. Chem. Soc. 1985, 107, 47004706.

(23) CCDC 2051069.

(24) This phosphirenium ion does not give enantiocontrol in catalysis, supporting our computational studies. See Supporting Information.

(25) (a) Gudat, D.; Nieger, M.; Schrott, M. Synthese Und Charakterisierung Stabiler Bis(Phosphonio)IsophosphindolyliumCarbonylmetallate Und Eines Kationischen Bis(Phosphonio)Isophosphindolylium-Gold-Komplexes. Chem. Ber. 1995, 128, 259266. (b) Sase, S.; Kano, N.; Kawashima, T. Pentacoordinate 1HPhosphirenes: Reactivity, Bonding Properties, and Substituent Effects on Their Structures and Thermal Stability. J. Org. Chem. 2006, 71, $5448-5456$

(26) Tsutsui, S.; Sakamoto, K.; Kabuto, C.; Kira, M. X-Ray Crystallographic Analysis of a 3-Silacyclopropene with Electronegative Substituents on Silicon. Organometallics 1998, 17, 3819-3821. 
(27) CCDC 2051070.

(28) (a) Corey, E. J.; Cho, H.; Rücker, C.; Hua, D. H. Studies with Trialkylsilyltriflates: New Syntheses and Applications. Tetrahedron Lett. 1981, 22, 3455-3458. (b) Aizpurua, J. M.; Palomo, C. Reagents and Synthetic Methods 55. New Methods for the Preparation of tButyldimethylsilyl Triflate and Trimethylsilyl Triflate. Tetrahedron Lett. 1985, 26, 6113-6114.

(29) See Supporting Information for DFT studies, which indicate that the base is not intimately involved in catalytic turnover.

(30) Barrett, A. N.; Sanderson, H. J.; Mahon, M. F.; Webster, R. L. Hydrophosphination Using $\left[\mathrm{GeCl}\left\{\mathrm{N}\left(\mathrm{SiMe}_{3}\right)_{2}\right\}_{3}\right]$ as a Pre-Catalyst. Chem. Commun. 2020, 56, 13623-13626.

(31) Qian, Y.; Dai, Q.; Li, Z.; Liu, Y.; Zhang, J. O-Phosphination of Aldehydes/Ketones toward Phosphoric Esters: Experimental and Mechanistic Studies. Org. Lett. 2020, 22, 4742-4748.

(32) Chong, C. C.; Hirao, H.; Kinjo, R. Metal-Free $\sigma$-Bond Metathesis in 1,3,2-Diazaphospholene-Catalyzed Hydroboration of Carbonyl Compounds. Angew. Chem., Int. Ed. 2015, 54, 190-194.

(33) Bassindale, A. R.; Stout, T. The Synthesis of Functionalised Silyltriflates. J. Organomet. Chem. 1984, 271, C1-C3.

(34) See Supporting Information, where Figure S44 in particular covers these alternative mechanisms computed.

(35) Burés, J. Variable Time Normalization Analysis: General Graphical Elucidation of Reaction Orders from Concentration Profiles. Angew. Chem., Int. Ed. 2016, 55, 16084-16087.

(36) (a) Parks, D. J.; Piers, W. E. Tris(Pentafluorophenyl)BoronCatalyzed Hydrosilation of Aromatic Aldehydes, Ketones, and Esters. J. Am. Chem. Soc. 1996, 118, 9440-9441. (b) Houghton, A. Y.; Hurmalainen, J.; Mansikkamäki, A.; Piers, W. E.; Tuononen, H. M. Direct Observation of a Borane-Silane Complex Involved in Frustrated Lewis-Pair-Mediated Hydrosilylations. Nat. Chem. 2014, 6, 983-988. (c) Lipke, M. C.; Liberman-Martin, A. L.; Tilley, T. D. Electrophilic Activation of Silicon-Hydrogen Bonds in Catalytic Hydrosilations. Angew. Chem., Int. Ed. 2017, 56, 2260-2294.

(37) Comprehensive investigation of the relative Lewis acidities of both the phosphorus center and the carbon-carbon double bond have been conducted. These calculations (see Supporting Information) indicate that there is $\pi$-anti-bonding character centered on the $\mathrm{C}=\mathrm{C}$, but this orbital-centered electrophilicity is likely to be a minor process compared to charge control observed at $\mathrm{P}^{+}$.

(38) An alternative initiation process was computed in which the ketone attacks the $\mathrm{C} 1$ position in II. $\mathrm{Si}-\mathrm{H}$ addition over the $\mathrm{C}=\mathrm{O}$ bond then leads to the hydrosilylation product and reforms II. For $3^{+}$ this process has an overall barrier of $+31.3 \mathrm{kcal} / \mathrm{mol}$ and so is not competitive with ketone attack at P. However, for $p$-OMe-substituted $10^{+}$this alternative pathway becomes more competitive $\left(\Delta G^{\ddagger}=28.6\right.$ $\mathrm{kcal} / \mathrm{mol} \mathrm{cf.}+28.3 \mathrm{kcal} / \mathrm{mol}$ ) and becomes the favored catalytic process due to a destabilization of TS(III-IV $)_{\mathrm{P}}$ in that case. Hydride transfer from silane to phosphorus in II was also characterised and involves a transition state at $+31.1 \mathrm{kcal} / \mathrm{mol}$. This may account for the observation of $\mathrm{HPPh}_{2}$ experimentally. See Supporting Information.

(39) Direct reaction of $\mathrm{III}_{\mathrm{H}, \mathrm{Z}}$ with ketone via TS $(\mathrm{III}-\mathbf{I V})_{\mathrm{H}, \mathrm{Z}}$ at -2.8 $\mathrm{kcal} / \mathrm{mol}$ results in the formation of $\mathbf{I V}_{\mathrm{H}, \mathrm{Z}}$ at $-28.7 \mathrm{kcal} / \mathrm{mol}$ and this accounts for the formation of $\mathbf{I V}_{\mathrm{H}, \mathrm{Z}}$ seen experimentally. Hydride transfer from $\mathbf{I V}_{\mathrm{H}, \mathrm{Z}}$ to the silylether cation has a barrier of $40.6 \mathrm{kcal} /$ mol.

(40) (a) Hatakeyama, S.; Mori, H.; Kitano, K.; Yamada, H.; Nishizawa, M. Efficient Reductive Etherification of Carbonyl Compounds with Alkoxytrimethylsilanes. Tetrahedron Lett. 1994, 35, 4367-4370. (b) Süsse, L.; Hermeke, J.; Oestreich, M. The Asymmetric Piers Hydrosilylation. J. Am. Chem. Soc. 2016, 138, 6940-6943. (c) Andrews, R. J.; Chitnis, S. S.; Stephan, D. W. Carbonyl and Olefin Hydrosilylation Mediated by an Air-Stable Phosphorus(III) Dication under Mild Conditions. Chem. Commun. 2019, 55, 5599-5602. (d) Kannan, R.; Chambenahalli, R.; Kumar, S.; Krishna, A.; Andrews, A. P.; Jemmis, E. D.; Venugopal, A. Organoaluminum Cations for Carbonyl Activation. Chem. Commun. 2019, 55, 14629-14632.
(41) Brasch, N. E.; Hamilton, I. G.; Krenske, E. H.; Wild, S. B. $\pi$ Ligand Exchange on Phosphenium Ions: Reversible Exchange between Free and Coordinated Alkynes in Phosphirenium Salts. Organometallics 2004, 23, 299-302.

(42) Goerigk, L.; Hansen, A.; Bauer, C.; Ehrlich, S.; Najibi, A.; Grimme, S. A Look at the Density Functional Theory Zoo with the Advanced Gmtkn55 Database for General Main Group Thermochemistry, Kinetics and Noncovalent Interactions. Phys. Chem. Chem. Phys. 2017, 19, 32184-32215. 